Article

\title{
The Synthesis and Characterization of a Novel One-Dimensional Bismuth (III) Coordination Polymer as a Precursor for the Production of Bismuth (III) Oxide Nanorods
}

\author{
Younes Hanifehpour ${ }^{1, *} \mathbb{C}$, Babak Mirtamizdoust ${ }^{2}$, Jaber Dadashi ${ }^{2}\left(\mathbb{D}\right.$, Ruiyao Wang ${ }^{3}\left(\mathbb{D}\right.$, Mahboube Rezaei ${ }^{2}$, \\ Mehdi Abdolmaleki ${ }^{1}$ and Sang Woo Joo ${ }^{4, *}$
}

check for updates

Citation: Hanifehpour, Y.; Mirtamizdoust, B.; Dadashi, J.; Wang, R.; Rezaei, M.; Abdolmaleki, M.; Joo, S.W. The Synthesis and

Characterization of a Novel One-Dimensional Bismuth (III) Coordination Polymer as a Precursor for the Production of Bismuth (III) Oxide Nanorods. Crystals 2022, 12, 113. https://doi.org/10.3390/ cryst12010113

Academic Editors: Alberto Girlando and Vladimir Fedin

Received: 9 September 2021

Accepted: 13 January 2022

Published: 15 January 2022

Publisher's Note: MDPI stays neutral with regard to jurisdictional claims in published maps and institutional affiliations.

Copyright: (C) 2022 by the authors. Licensee MDPI, Basel, Switzerland. This article is an open access article distributed under the terms and conditions of the Creative Commons Attribution (CC BY) license (https:// creativecommons.org/licenses/by/ $4.0 /)$.
1 Department of Chemistry, Sayyed Jamaleddin Asadabadi University, Asadabad 6541861841, Iran; m.abdolmaleki@sjau.ac.ir

2 Department of Chemistry, Faculty of Science, University of Qom, Qom 37185359, Iran; babakm.tamizdoust@gmail.com (B.M.); jaber_dadashi_95@yahoo.com (J.D.); mahboubeh.rezaei1998@gmail.com (M.R.)

3 Department of Chemistry, Xi'an Jiaotong-Liverpool University, Suzhou 215123, China; ruiyao.wang@xjtlu.edu.cn

4 WCU Nano Research Center, School of Mechanical Engineering, Yeungnam University, Gyeongsan 712-749, Korea

* Correspondence: Hanifehpour@sjau.ac.ir (Y.H.); swjoo@yu.ac.kr (S.W.J.)

\begin{abstract}
A novel Bi (III) coordination compound, $\left[\mathrm{Bi}(\mathrm{HQ})(\mathrm{Cl})_{4}\right]_{\mathrm{n}}((\mathrm{Q}=$ pyridine-4-carbaldehyde thiosemicarbazone), was prepared in this research using a sonochemical technique. SEM, infrared spectroscopy (IR), XRD, and single-crystal X-ray analysis were utilized to analyze the Bi(III) coordination compound. The structure determined using single-crystal X-ray crystallography indicates that the coordination compound is a 1D polymer in solid state and that the coordination number of bismuth (III) ions is six, $\left(\mathrm{BiSCl}_{5}\right)$, with one $\mathrm{S}$ donor from the organic ligand and five $\mathrm{Cl}$ donors from anions. It is equipped with a hemidirectional coordination sphere. It is interesting that the ligand has been protonated in the course of the reaction with a $\mathrm{Cl}^{-}$ion balancing the charge. This compound's supramolecular properties are directed and regulated by weak directional intermolecular interactions. Through $\pi-\pi$ stacking interactions, the chains interact with one another, forming a 3D framework. Thermolysis of the compound at $170{ }^{\circ} \mathrm{C}$ with oleic acid resulted in the formation of pure phase nanosized Bi (III) oxide. SEM technique was used to examine the morphology and size of the bismuth (III) oxide product produced.
\end{abstract}

Keywords: crystallography; ultrasonic irradiation; Bi(III) compound; crystal structure

\section{Introduction}

Coordination polymers, a class of solid-state materials characterized by an endless framework structure, are formed when metal ions and organic ligands self-assemble [1,2]. They continue to garner research interest due to their appealing shapes and many prospective applications in catalysis [3], magnetism [4], luminescence [5], drug delivery [6], gas separation [7], absorption [8], etc. It is self-evident that some architectures confer unique characteristics on materials, which are critical for their use $[9,10]$. However, developing and manufacturing new functional coordination polymers continue to be challenging at the moment.

The coordination sphere distortions in $\mathrm{Tl}(\mathrm{I}), \mathrm{Pb}(\mathrm{II})$, and $\mathrm{Bi}(\mathrm{III})$ compounds are of interest because they may be caused by the existence of a lone pair [11,12]. Bi(III) frameworks have garnered considerable attention due to their large ion radius, flexible coordination number, and the possibility of a stereochemically active lone pair of $6 s^{2}$ outer electrons. The stereochemical activity of valence shell electron lone pairs in polymeric and supramolecular substances could be intriguing, since a sudden accumulation of multiple bridging 
ligands could result in the disappearance of gaps, resulting in a less frequent holodirected configuration [13-16]. On the other hand, such as $\mathrm{Tl}(\mathrm{I})$ and $\mathrm{Pb}(\mathrm{II})$, the coordination sphere of $\mathrm{Bi}(\mathrm{III})$ is interesting (Scheme 1).

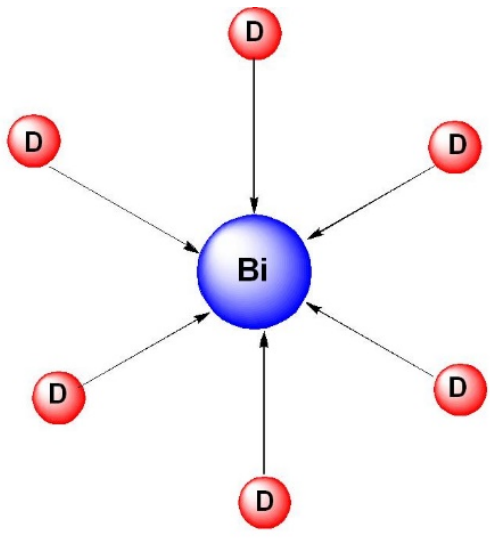

Holodirected

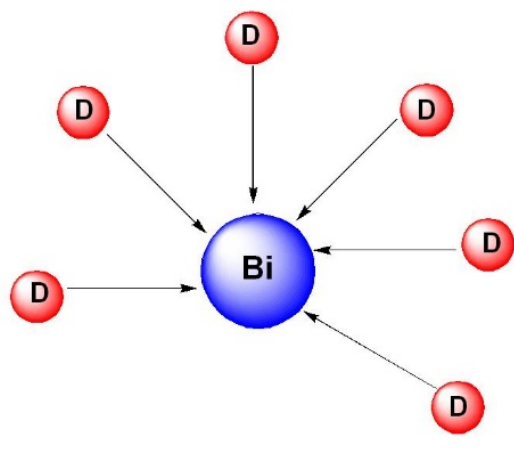

Hemidirected

Scheme 1. Bismuth $6 s^{2}$ pair stereochemical impact (a ligand's D donor atom).

Sonochemistry is a field of study wherein molecules undergo reactions when exposed to high-intensity ultrasound $(20 \mathrm{kHz}-10 \mathrm{MHz})$ [17]. Ultrasound causes physical or chemical alterations throughout cavitation, a process that involves the creation, development, and immediate collapsing of bubbles in fluids. Cavitation could produce warm spots with temperatures of approximately $5000^{\circ} \mathrm{C}$, pressures of approximately $500 \mathrm{~atm}$, and a life span of a few microseconds [18]. The high temperatures may accelerate chemical processes, but they can also stimulate the creation of nanoscale structures, most notably via the immediate production of many crystallization nuclei. This method has been extensively used to synthesize nanoscale structures of a variety of chemicals, and recently, many nanoscale materials have been produced with this method [19].

We are primarily interested in the design and synthesis of coordination polymers in this study. We recently published a study on the nanoscale production of different metal-organic coordination polymers [20-22]. The coordination characteristics of Bi(III) are investigated using a pyridine-4-carbaldehyde thiosemicarbazone ligand (Scheme 2). Then, we describe a sonochemical technique for producing nanostructures of the coordination compound and its use in the synthesis of nanoscaled Bi(III) oxide particles.<smiles>NC(=S)N/N=C/c1ccncc1</smiles>

Scheme 2. Pyridine-4-carbaldehyde thiosemicarbazide ligand.

\section{Experiment}

\subsection{Materials}

All solvents and reagents used were readily available commercially and were used without additional purification. The IR spectrum was acquired using $\mathrm{KBr}$ disks in $400-4000 \mathrm{~cm}^{-1}$ band on a Bruker Vector 22 FTIR spectrometer. Melting points were determined using Electrothermal 9100 equipment and are shown in their unaltered state. The ultrasonic generation was performed in a SONICA-2200 EP ultrasonic bath (frequency of $40 \mathrm{kHz}$ ). XPRD experiments were carried out utilizing a Panalytical X'pert diffractometer 
using monochromatized Cuk $\alpha$ radiation. Mercury 2.4 was used to generate modeled XPRD powder shapes based on single-crystal information [23].

The Scherrer method was used to determine the crystallographic diameters of chosen samples. Following coating of $\mathrm{Au}$, samples morphology was examined utilizing a scanning electron microscope (Hitachi, Japan). Data of diffraction for a single crystal of the synthesized coordination polymer were obtained at $298 \mathrm{~K}$ using a Bruker D8 VENTURE diffractometer, combined with a Photon II CCD detector and $\mathrm{Cu} K \alpha$ radiation. APEX 3 was used to collect the data, refine cell parameters, and reduce data [24].

We solved the structure using direct processes with SHELXS and anisotropically adjusted all $\mathrm{F}^{2}$ data utilizing a complete matrix weighted least-squares technique with $\mathrm{w}=1 /\left[\sigma^{2}\left(\mathrm{~F}_{\mathrm{o}}\right)^{2}+(0.035 \mathrm{P})^{2}\right]$ weight, where $p=\left(\mathrm{F}_{\mathrm{o}}^{2}+2 \mathrm{~F}_{\mathrm{c}}{ }^{2}\right) / 3$. Mercury 2.4 was used to create molecular displays. Table 1 contains the crystallographic data and arranging modification for the produced coordination polymer, whereas Table 2 contains the specified lengths and angles of the bond. The details about crystal structure of $\left[\mathrm{Bi}(\mathrm{HQ})(\mathrm{Cl})_{4}\right]_{\mathrm{n}}$ is provided in Supplementary Materials.

Table 1. Coordination compounds crystallographic data and structural refinements.

\begin{tabular}{|c|c|}
\hline Chemical Formula & $\mathrm{C}_{7} \mathrm{H}_{9} \mathrm{BiCl}_{4} \mathrm{~N}_{4} \mathrm{~S}$ \\
\hline$M_{\mathrm{r}}$ & 532.02 \\
\hline Crystal system, space group & Monoclinic, $\mathrm{P} 2{ }_{1} / \mathrm{c}$ \\
\hline Temperature $(\mathrm{K})$ & $298(2)$ \\
\hline$a, b, c(\AA)$ & $11.3205(4), 7.4736(3), 17.8244(6)$ \\
\hline$\beta\left(^{\circ}\right)$ & $97.9430(10)^{\circ}$ \\
\hline$V\left(\AA^{3}\right)$ & $1493.56(9)$ \\
\hline Z & 4 \\
\hline Crystal size $\left(\mathrm{mm}^{3}\right)$ & $0.200 \times 0.100 \times 0.030$ \\
\hline Theta range for data collection & 3.943 to $72.090^{\circ}$ \\
\hline Max. and min. transmission & $0.7535,0.2404$ \\
\hline$R_{\text {int }}$ & 0.0574 \\
\hline Absorption coefficient $\mathrm{mm}^{-1}$ & 30.948 \\
\hline$R, w R 2[I>2 \sigma(I)]$ & $0.0838,0.2181$ \\
\hline$R, w R 2$ (all data) & $0.0856,0.2247$ \\
\hline No. of reflections & 8804 \\
\hline No. of parameters & 155 \\
\hline No. of restraints & 0 \\
\hline Absorption correction & Multi-scan (Bruker SADABS) \\
\hline$\Delta \prime_{\max }, \Delta{ }^{\prime} \min \left(\mathrm{e} \AA^{-3}\right)$ & $5.003,-4.488$ \\
\hline Goodness-of-fit on $\mathrm{F}^{2}$ & 1.060 \\
\hline
\end{tabular}

Table 2. Selected lengths and angles of bond for $\left[\mathrm{Bi}(\mathrm{HQ})(\mathrm{Cl})_{4}\right]_{\mathrm{n}}$.

\begin{tabular}{|c|c|c|c|}
\hline $\mathrm{Bi}(1)-\mathrm{Cl}(3)$ & $2.542(3)$ & $\mathrm{Cl}(3)-\mathrm{Bi}(1)-\mathrm{Cl}(4)$ & $89.73(11)$ \\
\hline $\mathrm{Bi}(1)-\mathrm{Cl}(4)$ & $2.620(2)$ & $\mathrm{Cl}(3)-\mathrm{Bi}(1)-\mathrm{Cl}(2)$ & $88.27(14)$ \\
\hline $\mathrm{Bi}(1)-\mathrm{Cl}(2)$ & $2.714(4)$ & $\mathrm{Cl}(4)-\mathrm{Bi}(1)-\mathrm{Cl}(2)$ & $91.25(12)$ \\
\hline $\mathrm{Bi}(1)-\mathrm{Cl}(1)$ & $2.769(4)$ & $\mathrm{Cl}(3)-\mathrm{Bi}(1)-\mathrm{Cl}(1)$ & $97.02(14)$ \\
\hline $\operatorname{Bi}(1)-S(1)$ & $2.841(3)$ & $\mathrm{Cl}(4)-\mathrm{Bi}(1)-\mathrm{Cl}(1)$ & $170.90(12)$ \\
\hline $\mathrm{Bi}(1)-\mathrm{Cl}(1) \# 1$ & $2.861(3)$ & $\mathrm{Cl}(2)-\mathrm{Bi}(1)-\mathrm{Cl}(1)$ & $95.03(16)$ \\
\hline $\mathrm{N}(1)-\mathrm{H}(1 \mathrm{~A})$ & 0.86 & $\mathrm{Cl}(3)-\mathrm{Bi}(1)-\mathrm{S}(1)$ & $89.60(12)$ \\
\hline $\mathrm{Cl}(1)-\mathrm{Bi}(1)-\mathrm{S}(1)$ & $80.60(15)$ & $\mathrm{Cl}(4)-\mathrm{Bi}(1)-\mathrm{S}(1)$ & $93.41(9)$ \\
\hline $\mathrm{Cl}(3)-\mathrm{Bi}(1)-\mathrm{Cl}(1) \# 1$ & $173.81(14)$ & $\mathrm{Cl}(2)-\mathrm{Bi}(1)-\mathrm{S}(1)$ & $174.87(13)$ \\
\hline $\mathrm{Cl}(4)-\mathrm{Bi}(1)-\mathrm{Cl}(1) \# 1$ & $85.71(12)$ & $\mathrm{Cl}(2)-\mathrm{Bi}(1)-\mathrm{Cl}(1) \# 1$ & 87.64(17) \\
\hline $\mathrm{S}(1)-\mathrm{Bi}(1)-\mathrm{Cl}(1) \# 1$ & $94.85(14)$ & $\mathrm{Cl}(1)-\mathrm{Bi}(1)-\mathrm{Cl}(1) \# 1$ & $87.97(5)$ \\
\hline $\mathrm{Bi}(1)-\mathrm{Cl}(1)-\mathrm{Bi}(1) \# 2$ & $147.3(2)$ & & \\
\hline
\end{tabular}




\subsection{Isolated Single Crystal of $\left[\mathrm{Bi}(\mathrm{HQ})(\mathrm{Cl})_{4}\right]_{n}$ Synthesis}

We obtained single crystals of $\left[\mathrm{Bi}(\mathrm{HQ})(\mathrm{Cl})_{4}\right]_{\mathrm{n}}$ by combining bismuth(III) chloride ( $2 \mathrm{mmol}$ ) and the $\mathrm{Q}$ ligand $(2 \mathrm{mmol})$ in the main arm of a branching tube. $\mathrm{CH}_{3} \mathrm{OH}$ was supplied with care to completely fill both arms. After sealing the tube, the arm that contains the ligands was immersed in a $60^{\circ} \mathrm{C}$ oil bath; however, the other arm was stored at room temperature. After seven days of isolating and filtering the crystals inside the cooler arm, it was washed using acetone and ether and allowed to dry naturally (Figure 1) (yield: 52\%).

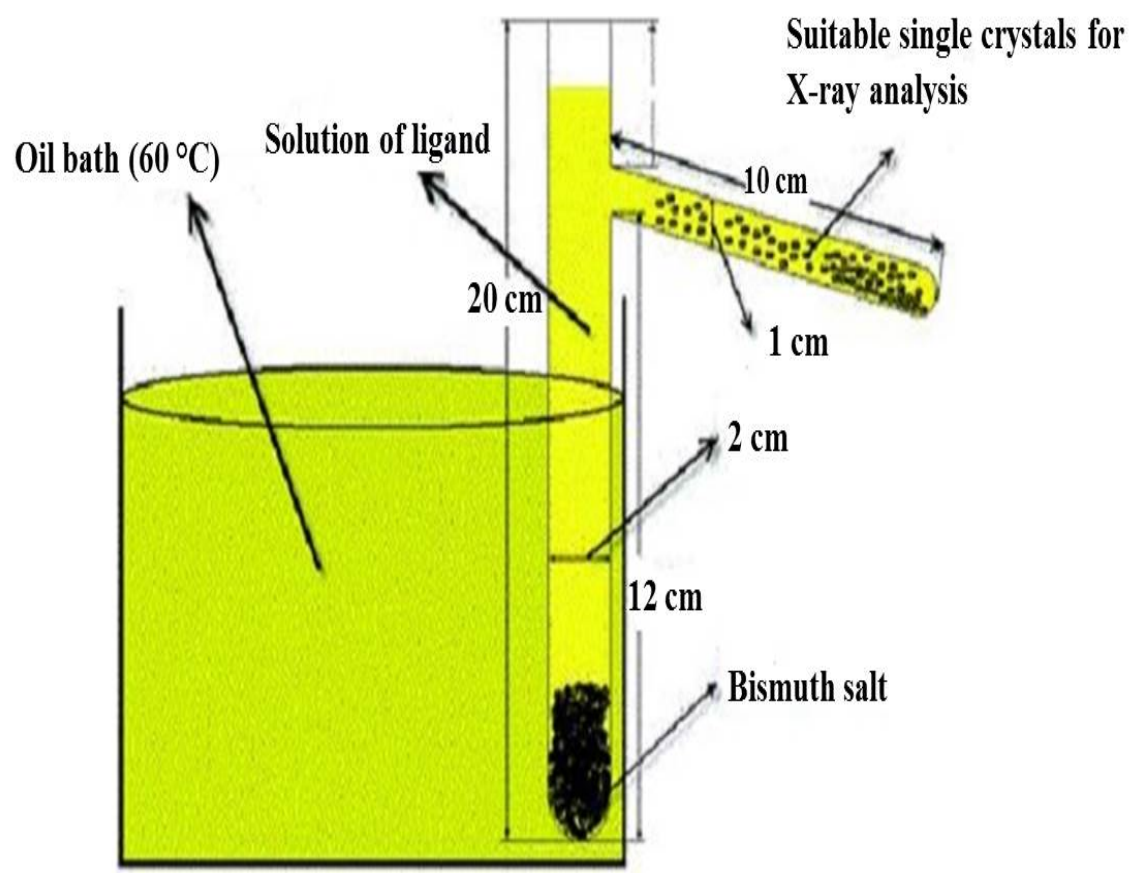

Figure 1. Branched tube method.

$\operatorname{FTIR}(\mathrm{KBr})=(632,801,1088,1491,1605,1636,2901,3441) \mathrm{cm}^{-1}$.

\subsection{Synthesis of the Compound $\left[\mathrm{Bi}(\mathrm{HQ})(\mathrm{Cl})_{4}\right]_{n}$ in Bulk Form}

We put $0.18 \mathrm{~g}$ of synthesized ligand and $0.315 \mathrm{~g}$ of bismuth (III) chloride into a small bottle, added approximately $20 \mathrm{~mL}$ of methanol, and stirred it for at least $60 \mathrm{~min}$ with a magnet to produce sedimentation. If sediment does not form, it is better to stop the system as a reflux system (for a minimum of $3 \mathrm{~h}$ ) to allow sediment to develop. Sediment formation occurred simultaneously in the examined system. The sediment was then screened and the FTIR spectra were analyzed (Yield: $49 \%$ ). The following are the major peaks in its infrared spectrum:

FTIR $(K B r)=(630,878,1108,1492,1594,2941,3262,3422) \mathrm{cm}^{-1}$.

\subsection{Synthesis of the $\left[\mathrm{Bi}(\mathrm{HQ})(\mathrm{Cl})_{4}\right]_{n}$ Nanostructure}

The nanostructure of $\left[\mathrm{Bi}(\mathrm{HQ})(\mathrm{Cl})_{4}\right]_{\mathrm{n}}$ was produced by placing $10 \mathrm{~mL}$ of a $0.1 \mathrm{M}$ solution of bismuth(III) chloride in water in a dense ultrasonic probe and dropwise adding $10 \mathrm{~mL}$ of a solution containing $0.1 \mathrm{M}$ of $\mathrm{Q}$ ligand in methanol/water. The precipitates obtained were screened, washed, and left to dry in the air (yield: $43 \%$ ).

FTIR $(K B r)=(793,815,1107,1493,1607,2982,3228,3380) \mathrm{cm}^{-1}$.

\section{Results and Discussion}

The combination of bismuth(III) chloride with pyridine-4-carbaldehyde thiosemicarbazone resulted in the formation of $\left[\mathrm{Bi}(\mathrm{HQ})(\mathrm{Cl})_{4}\right]_{\mathrm{n}}$, a novel 1-dimensional coordination molecule. The nanostructure of the chemical was evaluated using the ultrasonic method 
in an aqueous solution. The branched-tube method was used to produce appropriate single crystals of the prepared chemical for X-ray crystallography. Scheme 3 illustrates two distinct ways for producing $\left[\mathrm{Bi}(\mathrm{HQ})(\mathrm{Cl})_{4}\right]_{\mathrm{n}}$ materials.<smiles>NC(=S)N/N=C/c1ccncc1</smiles>

$\mathrm{L}=$ Schiff base ligand

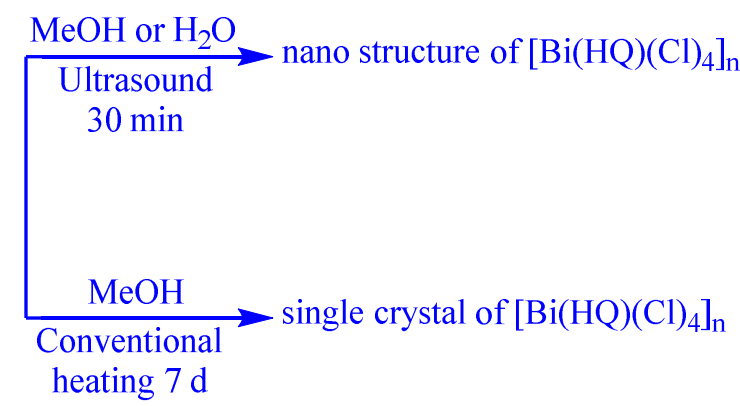

Scheme 3. Prepared materials and synthetic techniques.

The FTIR spectrum of the compound is shown in Figure 2 in its nano, bulk, and crystalline forms. Comparing these spectra reveals their resemblance, with the matching major peaks overlapping significantly.

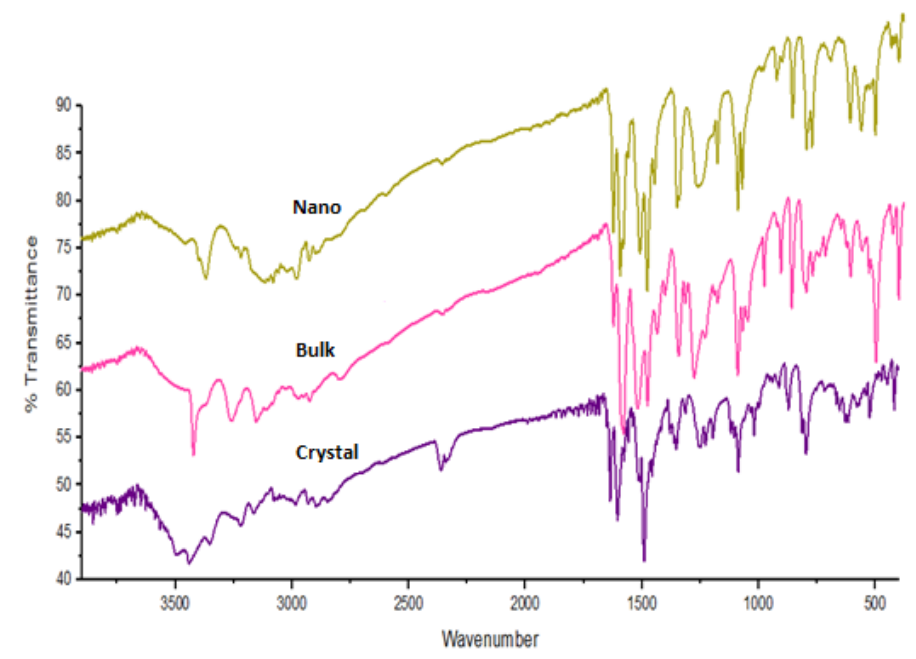

Figure 2. FTIR spectra of the coordination compound $\left[\mathrm{Bi}(\mathrm{HQ})(\mathrm{Cl})_{4}\right]_{\mathrm{n}}$ in nano, bulk, and crystalline form.

The bands of absorption with variable strengths in a range of $1400-1600 \mathrm{~cm}^{-1}$ in FTIR spectra of these chemicals are ascribed to the vibrations of the ligand pyridine ring, which is linked to the $\mathrm{C}=\mathrm{N}$ and $\mathrm{C}=\mathrm{C}$ bonds. Peaks associated with imine $\mathrm{C}=\mathrm{N}$ are observed as crisp bands in the range of $1600 \mathrm{~cm}^{-1}$ that have moved to shorter waves as a result of the ligand's coordination to the metal and the development of a compound with minimal displacement.

The tensile N-H peaks in the compound's vibrational spectra are located at $3235 \mathrm{~cm}^{-1}$ and show the existence of the ligand's N-H group when coupled to the central metal, as well as the presence of the ligand in the neutral structure during the compound's synthesis. For all three compounds, the associated band of the creation of a new $\mathrm{C}=\mathrm{N}$ bond is not seen, indicating that the L ligand contributed to the coordination of the metallic ion in the form of ketones. The $\mathrm{C}=\mathrm{S}$ group in the compound is detected with a little displacement in the vicinity of $1700 \mathrm{~cm}^{-1}$, indicating that it is coordinated to the metal.

The N-N group is detected in the $1052 \mathrm{~cm}^{-1}$ region, and this adsorption band is moved to lower wavenumbers in the spectra of all three compounds than in the ligand spectrum, indicating that the nitrogen atom of azomethine is not coordinated to the metallic ion. 
The findings of the study reveal that when ligand tautomerization occurs, the ligand takes part in the forming of compounds in enol form, and the absorption band of N-N is removed, $\mathrm{C}-\mathrm{N}$ and $\mathrm{N}-\mathrm{N}$ are shifted to high numbers, and a new $\mathrm{C}=\mathrm{N}$ bond is formed in the wavenumber $1400-1600 \mathrm{~cm}^{-1}$. Furthermore, the existence of the N-N band in the spectra of compounds shows that the ligand is not tautomerized in the solid form and that the ligand is in coordination with the metallic ion in the ketonic form. As can be observed, there is an excellent match in all regions between the nanomaterial, crystal, and manufactured bulk [11].

The produced nanoscale coordination polymer's surface morphology was studied using SEM. SEM analysis demonstrates that the produced nanoparticles are of varying sizes and shapes (Figure 3).

a

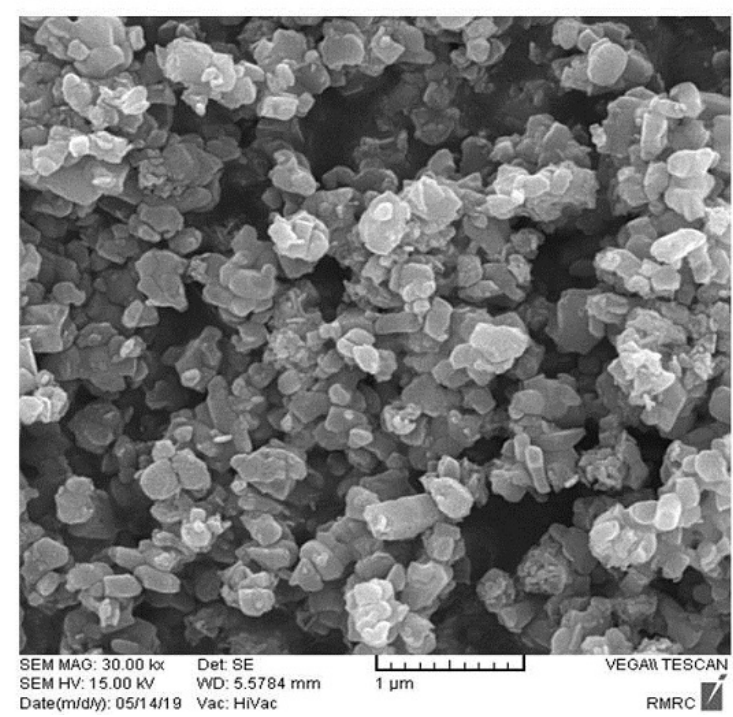

b

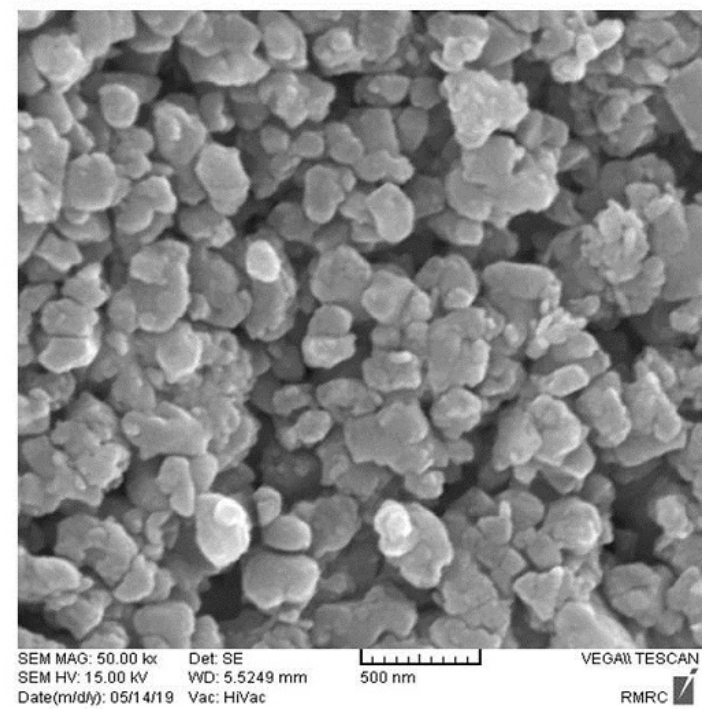

Figure 3. $\left[\mathrm{Bi}(\mathrm{HQ})(\mathrm{Cl})_{4}\right]_{\mathrm{n}} \mathrm{SEM}$ scans at various magnifications. (a) $1 \mu \mathrm{m}$ and (b) $500 \mathrm{~nm}$.

The generated XPRD pattern of $\left[\mathrm{Bi}(\mathrm{HQ})(\mathrm{Cl})_{4}\right]_{\mathrm{n}}$ is shown in Figure 4 in contrast to an experimental XRD pattern of a nanostructure. Acceptable matches by minor changes in $2 \theta$ were observed between the experimental and simulated XPRD patterns. It demonstrates that the production of nanoparticles through sonochemistry is equivalent to that produced via crystallography. The extension of the peaks shows that the particles are nanoscale in size.

In Figure 5, X-ray diffraction analysis reveals that the produced coordination product in solid is a $1 \mathrm{D}$ coordination polymer with the ligand monodentately linked to the bismuth metal through the $S$ atom. This compound has a $Z$ value of 4 and is formed in a monoclinic crystal lattice. It is a member of the space group $\mathrm{P} 22_{1} / \mathrm{c}$.

The unit cell is shown in Figure 6. The structural units are connected through symmetric components such as screw axes of 21 , glide planes, and symmetry centers. The screw axes $2{ }_{1}$ are parallel to axis $b$, and the two glide planes are perpendicular to axis $b$, as shown in Figure 7. The symmetry centers at the middle of a unit cell serve as a link between these units. 


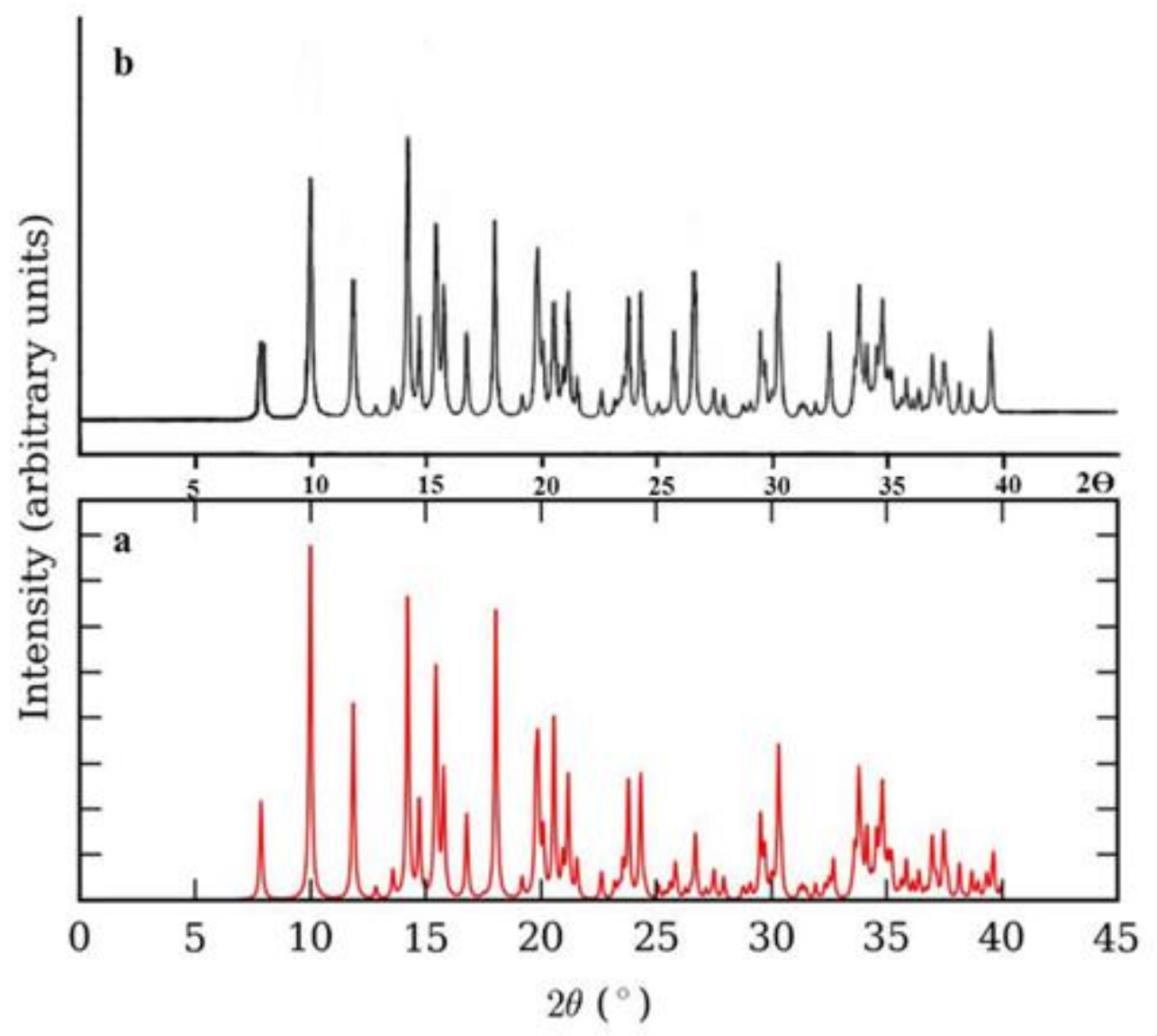

Figure 4. The XPRD designs of $\left[\mathrm{Bi}(\mathrm{HQ})(\mathrm{Cl})_{4}\right]_{n}$ : (a) simulated from single-crystal X-ray recordings and $(\mathbf{b})$ a nanostructure of coordination polymer produced using the sonochemical method.

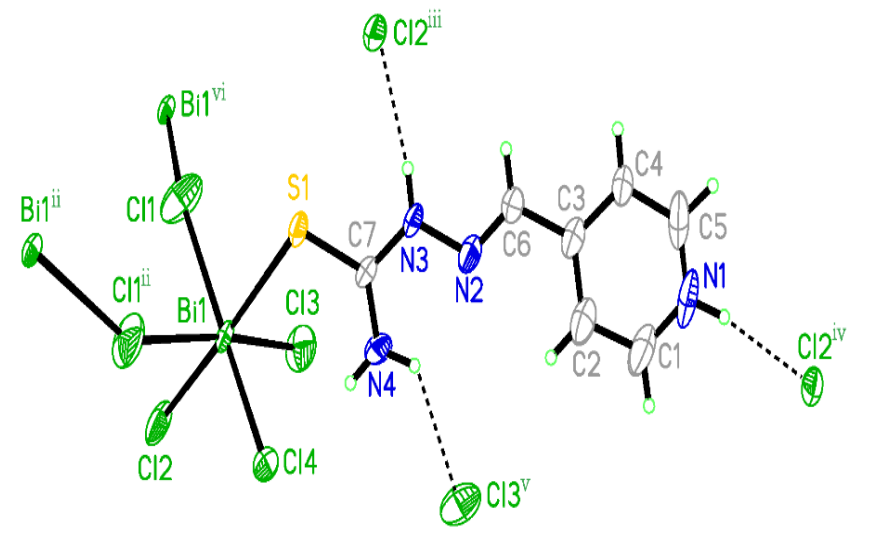

Figure 5. The crystal form of the coordination compound $\left[\mathrm{Bi}(\mathrm{HQ})(\mathrm{Cl})_{4}\right]_{\mathrm{n}}$ (Symmetry Code: \#2 $-\mathrm{x}+2$, $y+1 / 2 ; \# 3 x,-y+1 / 2, z+1 / 2 ; \# 4 x-1,-y+1 / 2, z+1 / 2 ; \# 5-x+1, y+1 / 2,-z+1 / 2 ; \# 6-x+2$, $\mathrm{y}-1 / 2,-\mathrm{z}+0.5)$. 


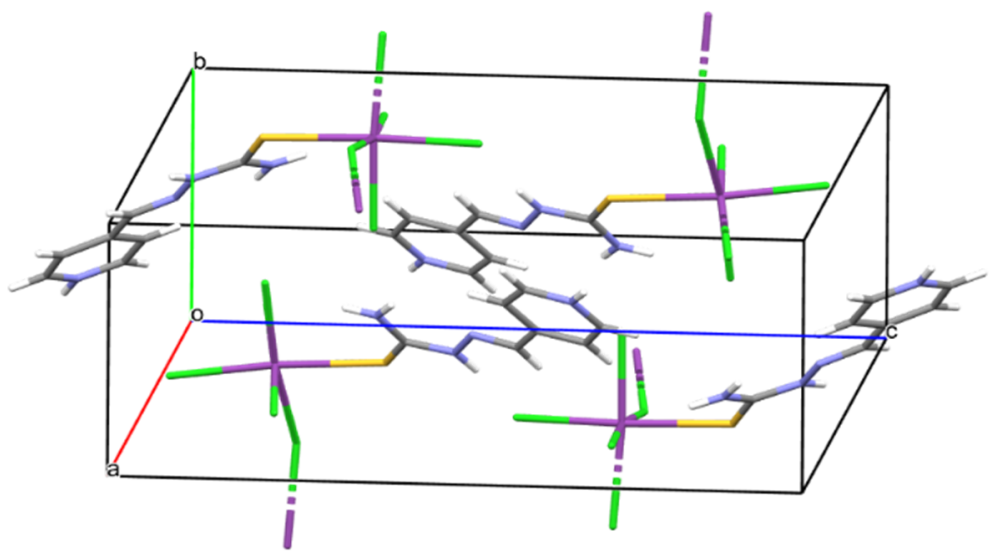

Figure 6. The structure of the $\left[\mathrm{Bi}(\mathrm{HQ})(\mathrm{Cl})_{4}\right]_{\mathrm{n}}$ compound unit cell.

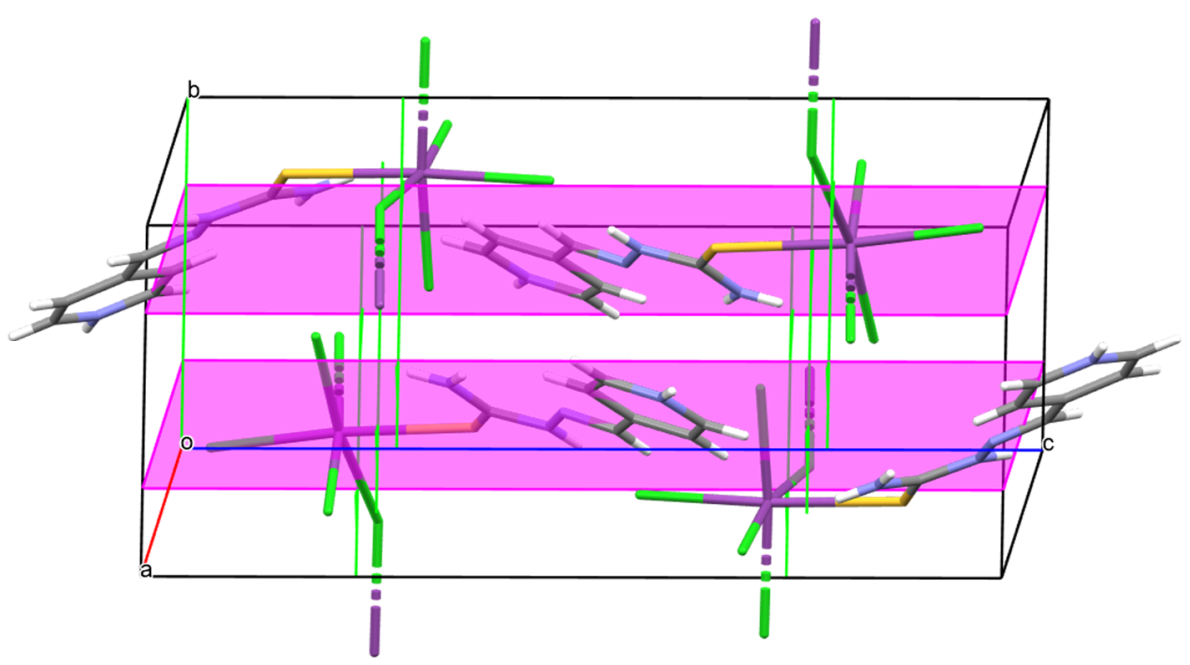

Figure 7. Symmetric elements of the $\left[\mathrm{Bi}(\mathrm{HQ})(\mathrm{Cl})_{4}\right]_{n}$ crystal shown along the axis $\mathrm{C}$ (green axes: screw axes $2_{1}$ and purple planes: glides planes; the dotted lines between some of the $\mathrm{Cl} 1$ and $\mathrm{Bi} 1$ represent the relative longer distance, 2.861(3) $\AA$, and weaker interaction between them).

A kind of bismuth with an asymmetric coordination sphere is found in this structure. Every bismuth central metal in this combination is connected to a sulfur atom of $Q$ ligands and five chlorine atoms, two of which are linked to other units that repeat and three of which are free. As a result of the $\mathrm{BiSCl}_{5}$ pattern, bismuth has a coordination number of six. Communication between structural units in the produced coordination polymer occurs through a single $\mathrm{Bi}-\mathrm{Cl}$ bond that is in the bridge mode, resulting in the creation of the polymeric structure.

The molecule lacks a symmetry center, and the bismuth-chlorine bonds are not identical in length. Additionally, the angles around the core metal atom are not identical in the coordination cortex; the angles formed by the ligand and the central metal are according to what is shown in Table 2. The HQ Ligand is covalently linked to the core metal through the $\mathrm{S}$ of thiosemicarbazide and functions as a monodentate ligand in the polymer shape. In solid form, this chemical is a 1D coordination compound. Figure 8 illustrates the compound's polymeric structure. This is comparable with other bismuth coordination compounds reported in the literature $[22,25,26]$. As a reported structure in reference [22], the coordination sphere of $\mathrm{Bi}(\mathrm{III})$ with seven coordination numbers was reported to be hemidirected with an asymmetrical shape. 


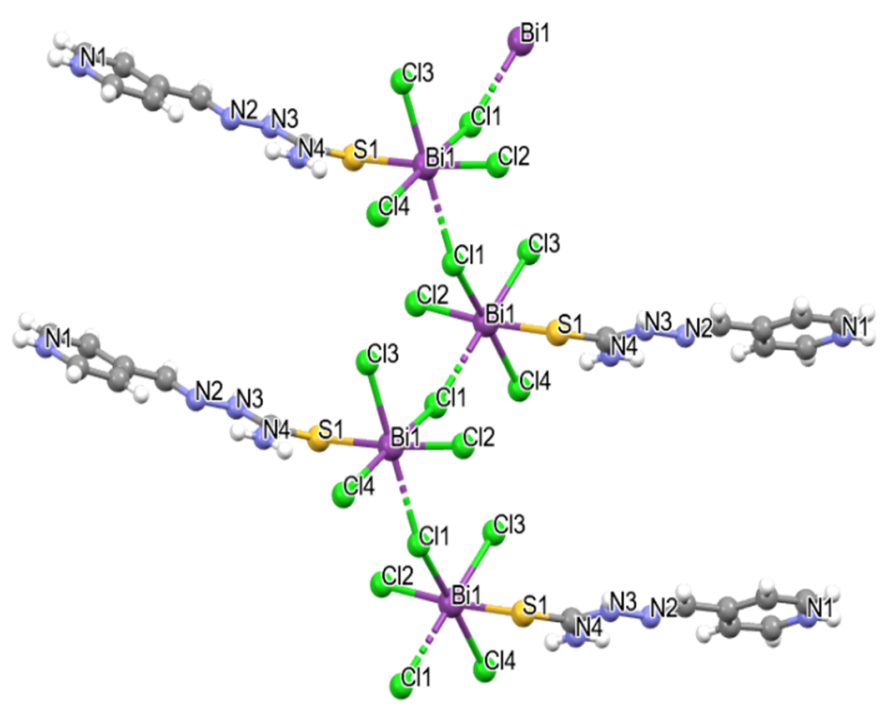

Figure 8. $\left[\mathrm{Bi}(\mathrm{HQ})(\mathrm{Cl})_{4}\right]_{\mathrm{n}}$ structure (The dotted lines between some of the $\mathrm{Cl} 1$ and $\mathrm{Bi1}$ represent the relative longer distance, 2.861(3) $\AA$, and weaker interaction between them).

It is interesting that the ligand has been protonated in the course of the reaction and that a $\mathrm{Cl}$ ion balances the charge. The pyridine nitrogen $\mathrm{N} 1$ was protonated during the reaction to balance the charges. This leads to a lower theoretical yield since the $\mathrm{Cl}$ atom is provided by one of the starting materials $\left(\mathrm{BiCl}_{3}\right)$.

In coordination polymers, in addition to coordination covalent strong bonds that cause the polymer to expand in a 1D step, weak interactions such as hydrogen and aromatic interactions cause self-accumulation of $1 \mathrm{D}$ chains and transform the structure into a 3D supermolecule via intermolecular interactions.

Without considering weak interactions, the composition has the structure of a 1D coordination polymer. By examining weak interactions, it is possible to detect the existence of seven hydrogen bonds in this structure, which transforms into a three-dimensional structure shown in Figure 9. Additionally, Table 3 shows $\mathrm{H}$ bonds.

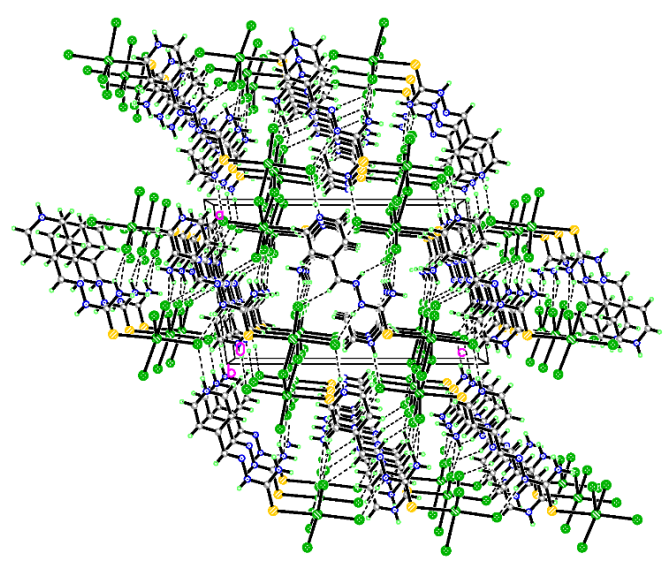

Figure 9. The 3D Structure of $\left[\mathrm{Bi}(\mathrm{HQ})(\mathrm{Cl})_{4}\right]_{\mathrm{n}}$ formed by labile interactions similar to hydrogen bonds. 
Table 3. The crystal structure of $\left[\mathrm{Bi}(\mathrm{HQ})(\mathrm{Cl})_{4}\right]_{n}$ reveals a number of noncovalent interactions.

\begin{tabular}{|c|c|c|c|c|}
\hline D-H...A & $\mathrm{d}(\mathrm{D}-\mathrm{H})$ & d(H...A) & $d(D \ldots A)$ & $<$ (DHA) \\
\hline $\mathrm{N} 1-\mathrm{H} 1 \mathrm{~A} \cdots \mathrm{Cl} 2 \mathrm{i}$ & 0.86 & 2.25 & $3.103(5)$ & 170.2 \\
\hline $\mathrm{N} 3-\mathrm{H} 3 \mathrm{~A} \cdots \mathrm{Cl} 2 \mathrm{ii}$ & 0.86 & 2.36 & $3.205(5)$ & 169.5 \\
\hline $\mathrm{N} 4-\mathrm{H} 4 \mathrm{~A} \cdots \mathrm{Cl} 3$ iii & 0.86 & 2.61 & 3.247 (5) & 131.9 \\
\hline $\mathrm{N} 4-\mathrm{H} 4 \mathrm{~A} \cdots \mathrm{Cl} 4 \mathrm{iv}$ & 0.86 & 2.95 & $2.452(5)$ & 119.1 \\
\hline N4-H4B $\cdots \mathrm{Cl} 4$ & 0.86 & 2.34 & $3.195(5)$ & 170.0 \\
\hline $\mathrm{C} 5-\mathrm{H} 5 \mathrm{~A} \cdots \mathrm{Cl} 3 \mathrm{v}$ & 0.93 & 2.91 & $3.661(5)$ & 138.9 \\
\hline C6-H6A $\cdots \mathrm{Cl} 4$ ii & 0.93 & 2.89 & $3.720(5)$ & 149.8 \\
\hline
\end{tabular}
$-1 / 2,-z+1 / 2 ;(\mathrm{v})-x+1,-y,-z+1$.

$\mathrm{Bi}_{2} \mathrm{O}_{3}$ nanorods were produced via thermolysis of $\mathbf{1}$ at $170{ }^{\circ} \mathrm{C}$ with oleic acid as a surfactant. The powder XRD patterns (Figure 10) match the standard pattern of the $\mathrm{Bi}_{2} \mathrm{O}_{3}$ tetragonal structure (JCPDS card file No. 76-1730), which confirms the formation of bismuth oxide. The average size of the particles was estimated by the Scherrer formula as $24 \mathrm{~nm}$.

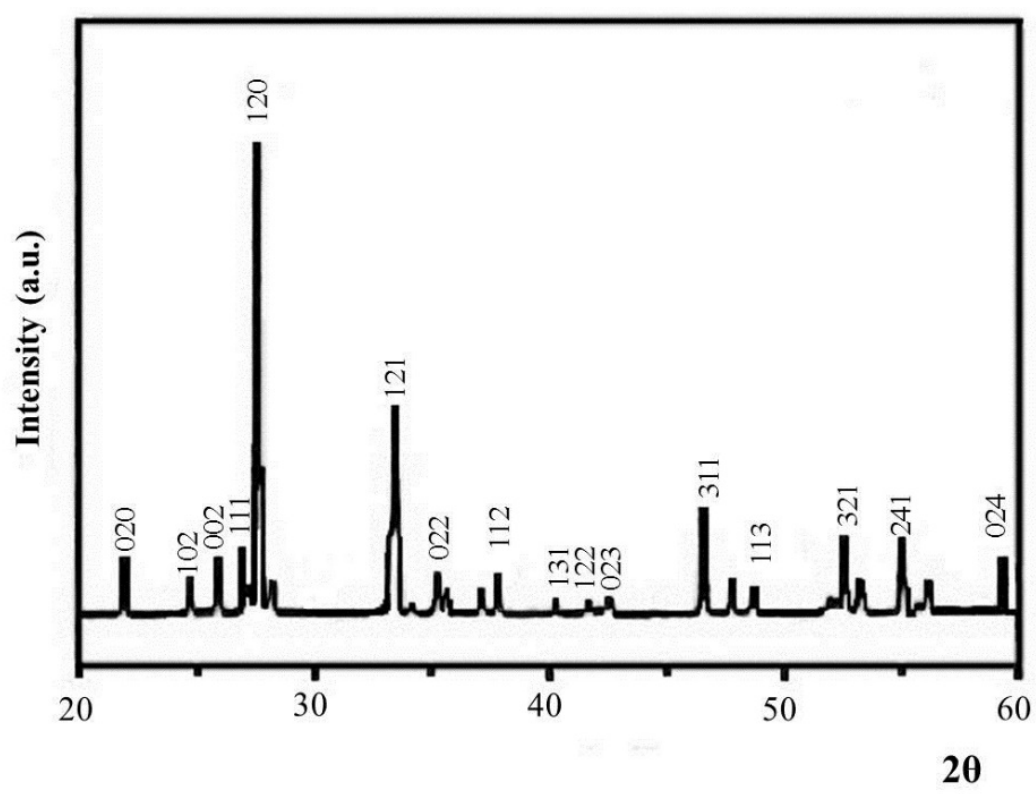

Figure 10. PXRD pattern of $\mathrm{Bi}_{2} \mathrm{O}_{3}$ nanorods prepared by thermolysis of compound 1 at $170{ }^{\circ} \mathrm{C}$.

Moreover, SEM images of the residue obtained from the thermolysis of 1 at $180{ }^{\circ} \mathrm{C}$ using oleic acid as the surfactant show that the $\mathrm{Bi}_{2} \mathrm{O}_{3}$ oxide NPs have a rod shape whose diameter is around 40-60 $\mathrm{nm}$ (Figure 11), comparable with reported in the literature [27-29].

Figure 12 displays the XPS spectra of $\mathrm{Bi}_{2} \mathrm{O}_{3}$ nano oxide. Two asymmetric peaks centered at $158.7 \mathrm{eV}$ and $163.9 \mathrm{eV}$ are due to the transitions of $4 \mathrm{f}_{7 / 2}$ and $4 \mathrm{f}_{5 / 2}$, respectively, and are attributed to $\mathrm{Bi}^{3+}$ ions in $\mathrm{Bi}_{2} \mathrm{O}_{3}$, crystal, which indicates that $\mathrm{Bi}^{3+}$ exists in the product in the form of bismuth oxide which is close to the reported values for crystalline $\mathrm{Bi}_{2} \mathrm{O}_{3}[30,31]$. The $\mathrm{O} 1 \mathrm{~s}$ spectrum for $\mathrm{Bi}_{2} \mathrm{O}_{3}$ indicates a peak at $531.1 \mathrm{eV}$, which is close to the value of $530.9 \mathrm{eV}$ reported in the literature [32]. 


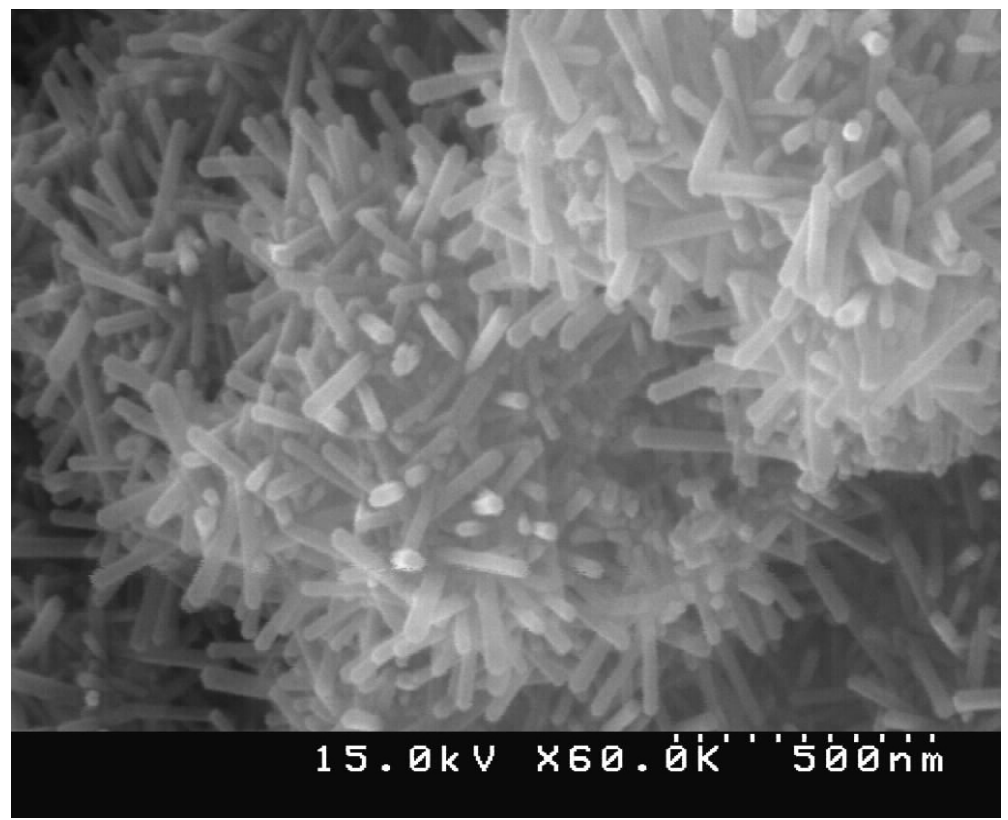

Figure 11. SEM image of $\mathrm{Bi}_{2} \mathrm{O}_{3}$ nanorods produced by thermolysis of nanostructure 1 at $170{ }^{\circ} \mathrm{C}$.
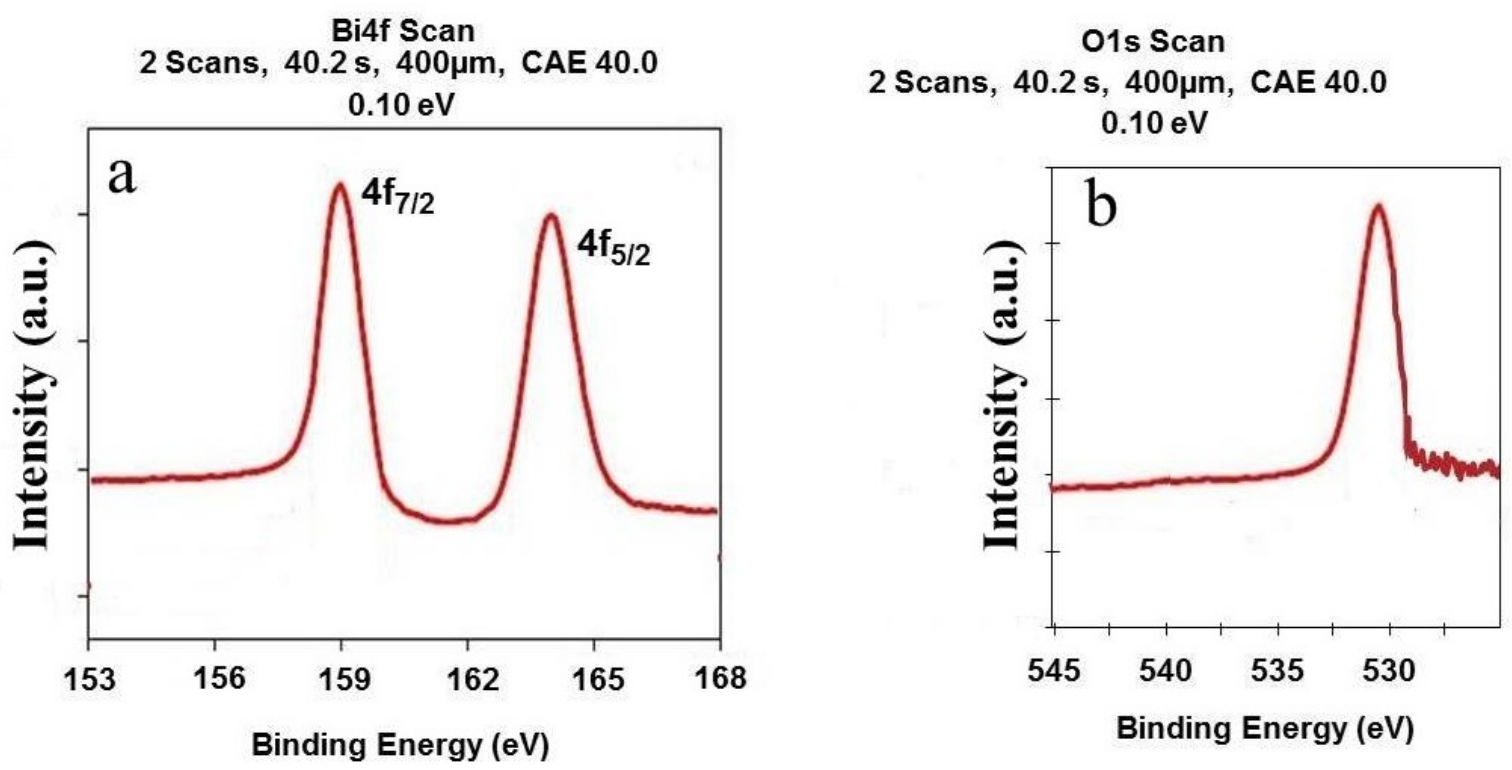

Figure 12. $\mathrm{XP}$ spectra of $\mathrm{Bi}_{2} \mathrm{O}_{3}$ nanorods (a) $\mathrm{Bi}$ and (b) $\mathrm{O}$ obtained by thermolysis of compound $\mathbf{1}$.

\section{Conclusions}

In this study, a new bismuth (II) coordination polymer $\left[\mathrm{Bi}(\mathrm{HQ})(\mathrm{Cl})_{4}\right]_{n}$ nanostructure was produced using ultrasonic, and its crystal structure was examined. The novel coordination compound was structurally characterized using spectrophotometry, single-crystal crystallography, and SEM. In solid state, the compound's structure resulted in a 1D coordination polymer. The coordination number of Bi (III) ions was found to be six by using one sulfur atom from the organic ligand and five $\mathrm{Cl}$ atoms from anions. It is interesting that the ligand was protonated in the course of the reaction and that a $\mathrm{Cl}$ ion balanced the charge. The complete system exhibited a 3D structure due to numerous weak interactions. Moreover, the calcination of compound $\mathbf{1}$ by thermolysis of 1 at $170{ }^{\circ} \mathrm{C}$ using oleic acid occurred as the surfactant yielded uniform $\mathrm{Bi}_{2} \mathrm{O}_{3}$ nanorods. 
Supplementary Materials: Crystallographic data for the structure reported in this paper have been deposited with The Cambridge Crystallographic Data Centre as supplementary publication CCDC2108919 for $\left[\mathrm{Bi}(\mathrm{HQ})(\mathrm{Cl})_{4}\right]_{\mathrm{n}}(\mathbf{1})$. Copies of the data can be obtained by request from the CCDC, 12 Union Road, Cambridge CB2 1EZ, UK. Fax: +44 1223 336033, e-mail: deposit@ccdc.cam.ac.uk.

Author Contributions: Supervision, writing-review and editing, Y.H.; writing-review and editing, B.M.; writing-original draft preparation, J.D.; X-ray analysis, writing-review and editing, R.W.; writing-original draft preparation, M.R.; formal analysis, M.A.; project administration, writing-review and editing, S.W.J. All authors have read and agreed to the published version of the manuscript.

Funding: This study was funded by the 2021 Yeungnam University Research Grant.

Institutional Review Board Statement: Not applicable.

Informed Consent Statement: Not applicable.

Data Availability Statement: Not applicable.

Acknowledgments: The authors thank Sayyed Jamaledin Asadabadi University and Qom University for their support.

Conflicts of Interest: The authors declare no conflict of interest.

\section{References}

1. Engel, E.R.; Scott, J.L. Advances in the green chemistry of coordination polymer materials. Green Chem. 2020, $22,3693-3715$. [CrossRef]

2. Liu, J.Q.; Luo, Z.D.; Ying, P.; Singh, A.K.; Trivedi, M.; Kumar, A. Recent developments in luminescent coordination polymers: Designing strategies, sensing application and theoretical evidences. Coord. Chem. Rev. 2020, 406, 213145. [CrossRef]

3. Farrusseng, D.; Aguado, S.; Pinel, C. Minireviews MOFs in Catalysis Metal—Organic Frameworks: Opportunities for Catalysis. Angew. Chem. Int. Ed. 2009, 48, 7502-7513. [CrossRef] [PubMed]

4. Kurmoo, M. Magnetic metal-organic frameworks. Chem. Soc. Rev. 2009, 38, 1353. [CrossRef] [PubMed]

5. Allendorf, M.D.; Bauer, C.A.; Bhakta, R.K.; Houk, R.J.T. Luminescent metal-organic frameworks. Chem. Soc. Rev. 2009, 38, 1330. [CrossRef]

6. Horcajada, P.; Gref, R.; Baati, T.; Allan, P.K.; Maurin, G.; Couvreur, P.; Férey, G.; Morris, R.E.; Serre, C. [LER ESSE DE NOVO] Metal-Organic Frameworks in Biomedicine. Chem. Rev. 2012, 112, 1232-1268. [CrossRef] [PubMed]

7. Bastani, D.; Esmaeili, N.; Asadollahi, M. Polymeric mixed matrix membranes containing zeolites as a filler for gas separation applications: A review. J. Ind. Eng. Chem. 2013, 19, 375-393. [CrossRef]

8. Zhang, Z.; Zhao, Y.; Gong, Q.; Li, Z.; Li, J. MOFs for $\mathrm{CO}_{2}$ capture and separation from flue gas mixtures: The effect of multifunctional sites on their adsorption capacity and selectivity. Chem. Commun. 2013, 49, 653-661. [CrossRef]

9. Gu, J.Z.; Wen, M.; Liang, X.X.; Shi, Z.F.; Kirillova, M.V.; Kirillov, A.M. Multifunctional aromatic carboxylic acids as versatile building blocks for hydrothermal design of coordination polymers. Crystals 2018, 8, 83. [CrossRef]

10. Song, B.H.; Ding, X.; Li, C.; An, G.F. Synthesis, crystal structures, and anti-liver cancer activity studies on three similar coordination polymers. Crystals 2018, 8, 207. [CrossRef]

11. Dadashi, J.; Hanifehpour, Y.; Mirtamizdoust, B.; Abdolmaleki, M.; Jegarkandi, E.M.; Rezaei, M.; Joo, S.W. Ultrasound-Assisted Synthesis and DFT Calculations of the Novel 1D Pb (II) Coordination Polymer with Thiosemicarbazone Derivative Ligand and Its Use for Preparation of PbO Clusters. Crystals 2021, 11, 682. [CrossRef]

12. Sorg, J.R.; Wehner, T.; Matthes, P.R.; Sure, R.; Grimme, S.; Heine, J.; Buschbaum, K.M. Bismuth as Versatile Cation for Luminescence in Coordination Polymers from BiX3/4,4-bipy: Understanding of Photophysics by Quantum Chemical Calculations and Structural Parallels to Lanthanides. Dalton Trans. 2018, 47, 7669-7681. [CrossRef]

13. Andleeb, S.; Din, I. Recent progress in designing the synthetic strategies for bismuth based complexes. J. Organomet. Chem. 2019, 898, 120871. [CrossRef]

14. Wibowo, A.C.; Smith, M.D.; Yeon, J.; Halasyamani, P.S.; Loye, H.C. Novel 3D bismuth-based coordination polymers: Synthesis, structure, and second harmonic generation properties. J. Solid State Chem. 2012, 195, 94-100. [CrossRef]

15. Roodsari, M.S.; Shaabani, B.; Mirtamizdoust, B.; Dusek, M.; Fejfarova, K. Sonochemical Synthesis of Bismuth (III) Nano Coordination Compound and Direct Synthesis of Bi2O3 Nanoparticles from a Bismuth (III) Nano Coordination Compound Precursor. Inorg. Organomet. Polym. 2015, 25, 1226-1232. [CrossRef]

16. Kowalik, M.; Masternak, J.; Łakomska, I.; Kazimierczuk, K.; Zawilak-Pawlik, A.; Szczepanowski, P.; Khavryuchenko, O.V.; Barszcz, B. Structural Insights into New Bi(III) Coordination Polymers with Pyridine-2,3-Dicarboxylic Acid: Photoluminescence Properties and Anti-Helicobacter pylori Activity. Int. J. Mol. Sci. 2020, 21, 8696. [CrossRef] [PubMed]

17. Pokhrel, N.; Vabbina, P.K.; Pala, N. Sonochemistry: Science and Engineering. Ultrason. Sonochem. 2016, 29, 104-128. [CrossRef] [PubMed] 
18. Mason, T.J. Ultrasound in synthetic organic chemistry. Chem. Soc. Rev. 1997, 26, 443-451. [CrossRef]

19. Suslick, K.S.; Price, G.J. Applications of ultrasound to materials chemistry. Ann. Rev. Mater. Sci. 1999, 29, 295-326. [CrossRef]

20. Hanifehpour, Y.; Dadashi, J.; Mirtamizdoust, B. Ultrasound-Assisted Synthesis and Crystal Structure of Novel 2D Cd (II) MetalOrganic Coordination Polymer with Nitrite End Stop Ligand as a Precursor for Preparation of CdO Nanoparticles. Crystals 2021, 11, 197. [CrossRef]

21. Mirtamizdoust, B.; Hanifehpour, Y.; Behzadfar, E.; Roodsari, M.S.; Jung, J.H.; Joo, S.W. A novel nano-structured three-dimensional supramolecular metal-organic framework for cadmium (II): A new precursor for producing nano cadmium oxide. J. Mol. Struct. 2020, 1201, 127191. [CrossRef]

22. Hanifehpour, Y.; Mirtamizdoust, B.; Hatami, M.; Khomami, B.; Joo, S.W. Synthesis and structural characterization of new bismuth (III) nano coordination polymer: A precursor to produce pure phase nano-sized bismuth (III) oxide. J. Mol. Struct. 2015, 1091, 43-48. [CrossRef]

23. Mercury 2.4: Copyright Cambridge Crystallographic Data Centre; Oxford Diffraction Limited: Cambridge, UK, $2001-2010$.

24. Oxford Diffraction. CrysAlis RED and CrysAlis CCD Software (Ver. 1.171.32.5); Oxford Diffraction Ltd.: Oxfordshire, UK, 2004.

25. Mahmoud, W.E.; Al-Ghamdi, A.A.; Al-Agel, F. Synthesis and optical properties of poly (vinyl acetate)/bismuth oxide nanorods. Polym. Adv. Technol. 2011, 22, 2055-2061. [CrossRef]

26. Solanki, P.R.; Singh, J.; Rupavali, B.; Tiwari, S.; Malhotra, B.D. Bismuth oxide nanorods based immunosensor for mycotoxin detection. Mater. Sci. Eng. C 2017, 70, 564-571. [CrossRef] [PubMed]

27. Soltanzadeh, N.; Morsali, A. Sonochemical synthesis of a new nano-structures bismuth (III) supramolecular compound: New precursor for the preparation of bismuth (III) oxide nano-rods and bismuth (III) iodide nano-wires. Ultrason. Sonochem. 2010, 17, 139-144. [CrossRef]

28. Luo, H.; Yang, R.G.; Chen, Z.H.; Zhong, G.Q. Three bismuth (III) complexes constructed by N-containing heterocyclic carboxylic acids: Synthesis, crystal structure and photocatalytic activity. J. Solid State Chem. 2021, 300, 122256. [CrossRef]

29. Belghoul, B.; Welterlich, I.; Maier, A.; Toutianoush, A.; Rabindranath, A.R.; Tieke, B. Supramolecular sequential assembly of polymer thin films based on dimeric, dendrimeric, and polymeric schiff-base ligands and metal ions. Langmuir 2007, 23, 5062-5069. [CrossRef]

30. Fan, H.T.; Pan, S.S.; Teng, X.M.; Ye, C.; Li, G.H.; Zhang, L.D. $\delta$-Bi2O3 thin films prepared by reactive sputtering: Fabrication and characterization. Thin Solid Films 2006, 513, 142-147. [CrossRef]

31. Shinde, P.V.; Ghule, B.G.; Shaikh, S.F.; Shinde, N.M.; Sangale, S.S.; Jadhav, V.V.; Yoon, S.-Y.; Kim, K.H.; Mane, R.S. Microwaveassisted hierarchical bismuth oxide worm-like nanostructured films as room-temperature hydrogen gas sensors. J. Alloy. Compd. 2019, 802, 244-251. [CrossRef]

32. Zingg, D.S.; Hercules, D.M. Electron spectroscopy for chemical analysis studies of lead sulfide oxidation. J. Phys. Chem. 1978, 82, 1992-1995. [CrossRef] 